\title{
HOW THE COVID-19 CRISIS IS AFFECTING CUSTOMERS' INTENTION TO USE ISLAMIC FINTECH SERVICES: EVIDENCE FROM INDONESIA
}

\author{
Dety Nurfadilah ${ }^{1}$ and Sudarmawan Samidi ${ }^{2}$ \\ ${ }^{1}$ Sekolah Tinggi Manajemen IPMI, Indonesia, dety.nurfadilah@ipmi.ac.id \\ ${ }^{2}$ Sekolah Tinggi Manajemen IPMI, Indonesia, sudarmawan.samidi@ipmi.ac.id
}

\begin{abstract}
The objective of this study is to investigate the factors that are affecting customers' intention to use Islamic FinTech services during the Covid-19 crisis. It expands the technology acceptance model (TAM) by adding government support as a new variable for the context of Islamic FinTech services during the pandemic. Using TAM as a framework, we propose a model outlining the impact of government regulation, perceived usefulness, perceived ease of use, perceived trust, and user innovativeness on consumer attitude behaviour and the intention to use Islamic FinTech services, such as payment and peer-to-peer lending. 220 sets of data were collected from an online survey and analysed using partial least squares-structural equation modelling (PLS-SEM). The results show that government support for Islamic FinTech during the Covid-19 pandemic has had an indirect impact on attitude behaviour in using Islamic services through perceived ease of use and perceived usefulness. Attitude behaviour was found to have an impact on intention.
\end{abstract}

Keywords: Islamic fintech, Government support, User innovativeness, Customer behavior. JEL classification: D12; G23; O14; O33.

\author{
Article history: \\ Received : October 9, 2020 \\ Revised : : January 14, 2021 \\ Accepted : : March 1, 2021 \\ Available online : March 31, 2021
}

https://doi.org/10.21098/jimf.v7i0.1318 


\section{INTRODUCTION}

\subsection{Background}

The coronavirus pandemic (Covid-19) is considered to be a unique health crisis. Unlike previous pandemics, such as SARS and MERS, this one is affecting almost all economic conditions (Farooq, Laato, \& Islam, 2020). The impact of the virus has also affected global economic growth, which is predicted to slow down to -4.9 percent (IMF, 2020). In Indonesia, the Composite Stock Price Index (IHSG) has seen a decline, and the condition of the capital market has also slowed down.

The majority of businesses have been temporarily shut down due to various government responses to the pandemic, namely lockdowns, large-scale social restrictions, curfews, and border closures, which have led to widespread new unemployment and salary cuts (Mathew, 2020), and also intensified poverty (McKinsey, 2020). Based on the statistical data provided by the United Nations Development Programme (2020), 79\% of SMEs in Indonesia, specifically young ones, have faced negative impact, with $21 \%$ of business closing down and $58 \%$ seeing a fall in their financial turnover of up to $81 \%$. Their major challenges are lower income, higher costs of production, difficulty in accessing capital loans, and struggling to secure traditional financing from the banking sector, thus leading to disruption to their cash flow.

As well the negative impacts, the pandemic is also affecting the way people use technology for their financial activities, such as payment transactions and lending. Among the digital payment providers in Indonesia, such as Doku, Kartuku, iPaymu, Finnet, and Xendit, the first Islamic payment application which facilitates various types of payments, namely LinkAja Syariah, has joined the market. According to Aldila (2020), LinkAja Syariah registered 140,000 users in July 2020, which increased to 1.6 million by December 2020. This alternative mode of payment has gained popularity in line with the increased number of transactions in e-commerce. The changes in consumer behaviour, from cash transactions to a modern mobile system, is a good sign for the Islamic FinTech industry.

Some small businesses and young entrepreneurs who are struggling to secure traditional financing from the banking sector are also turning to Islamic peer-topeer lending as an alternative. Sari (2020) found that Islamic peer-to-peer lending companies were able to provide financing of up to Rp1.7 trillion, with a growth rate of $198 \% .85 \%$ of borrowers lived on Java Islands, $70 \%$ of which were dominated by online MSMEs in agriculture, basic materials, food and beverages, and the health sector (Fadila, 2020). This shows that Islamic peer-to-peer lending can optimise the financing of the MSME sector during and after the Covid-19 pandemic (Bella, 2020). The Securities Commission Malaysia (2020) also added that the emergence of advanced technology in Islamic finance through peer-to-peer lending products will promote better financial inclusion for non-users of formal services who have difficulty accessing financial services due to culture or religion, lack of information, or insufficient income with high-risk business.

In response to the Covid crisis in Indonesia, government support during the pandemic has been very responsive. First, it allocated funds for the National Economic Recovery program, also known as the program Pemulihan Ekonomi Nasional (PEN), and expanded partnership strategies between Islamic financial institutions and FinTech in distributing Islamic financing to MSMEs; for example, 
PT Bank Syariah Mandiri (Mandiri Syariah) and PT Alami Fintek Sharia (Wiratmini, 2020). The goal is that MSMEs who are not yet connected to the banking industry (being unbankable) can gain access to online financing through FinTech companies (IMF, 2020).

Second, the growth of Islamic FinTech is also helped by the physical and digital infrastructure, such as ports, airports, and satellites, which support the communication network. In 2021, the government is planning to allocate a budget of Rp413 trillion for infrastructure and Rp30 trillion for information and communication technology. These funds will be used for the construction of internet networks in more than 12,377 public service locations, the building of a national data centre, and for digitisation in the education sector (Ministry of Finance of the Republic of Indonesia, 2020).

Third, regulation plays an important role in creating a conducive, prudent, and solid ecosystem for the Islamic finance industry (Alam, Gupta \& Zameni, 2019). Currently, there are fatwa issued by the National Sharia Board - Indonesian Council of Ulama (Dewan Syariah Nasional - MUI) including No.117/2018 concerning Information Technology-based Financing Services with Islamic Principles, and No.116/2017 concerning electronic money. In addition to these, the Financial Services Authority (OJK) is drafting a revision of regulation POJK No.77/2016 concerning Information Technology-Based Lending and Borrowing Services. This revised regulation is expected to accelerate economic growth, which is currently experiencing a slowdown due to the Covid-19 pandemic. Finally, the government is promoting inclusion and literacy programs. Although the government is giving support to digitalisation during the outbreak, the challenges remain, such as low financial and digital literacy, low user trust, low mobile wallet penetration rates, and regulation to support consumer data protection.

Previous studies of customer intention to use Islamic FinTech in Indonesia are very limited. Darmansyah, Fianto \& Hendratmi (2020) analysed factors that affect such intention by comparing three models, namely the theory of planned behaviour, the theory acceptance model, and the theory of reasoned action. Another study conducted by Shaikh, Qureshi, Noordin, Shaikh, Khan \& Shahbaz (2020) analysed five factors (consumer innovativeness, self-efficacy, perceived usefulness, perceive ease of use, and subjective norms) that influenced customer intention to use Islamic FinTech services in Malaysia, while the majority of other researchers have focused on mobile banking (Elhajjar \& Ouiada, 2019; Singh \& Srivastava, 2020; Munoz-Leiva, Climent-Climent \& Liébana-Cabanillas, 2017), or digital payment (Amalia, 2018).

This study is original for the following reasons. First, Al nawayseh (2020) conducted a study of the factors that affected customers' choice of FinTech applications during the Covid-19 pandemic. The study used social influence, benefits, risks, and trust as independent variables. The study of Shaikh et al. (2020) examined the factors that influence customers' intention to use Islamic FinTech in the context of Malaysia, one of the potential markets for Islamic-compliant products. The study used perceived usefulness, perceived ease of use, consumer innovativeness, self-efficacy, and subjective norms as the independent variables, and Islamic FinTech acceptance as the dependent variable. Usman, Mulia, Chairy \& Widowati (2020) conducted a study of customers' intention to use FinTech in the 
context of zakat and donation. This study used trust, image, religiosity, perceived ease of use, perceived usefulness, subjective norms, and attitude as independent variables, and intention as the dependent variable.

While previous studies have mainly considered perceived ease of use, perceived usefulness, perceived trust, ability to use technology, and attitude, we contend that government support may also influence the intention to use Islamic FinTech. Government support is also required to facilitate its growth by developing specific regulations, improving infrastructure, providing skilled human capital, and providing venture funds. Therefore, this study aims to fill a gap in the literature by examining a new variable, government support, which is yet to be tested in the context of Islamic FinTech. By confirming its influence on strengthening customer intention with empirical support, this study provides new insights into the topic of Islamic FinTech.

Second, Indonesia, as one of the potential markets for Islamic finance products, with $87.2 \%$ of the population being Muslim and $97 \%$ of businesses being micro, small, and medium enterprises, has the potential to strengthen its economic growth by optimising the role of Islamic FinTech. Although such technology has attracted the interest of stakeholders, its long-term usage remains uncertain (Ryu, 2018). Further analysis and observation on the continuance of customers' intention to use Islamic FinTech services during times of crisis is crucial. To the best of the author's knowledge, only one study, conducted by Al nawayseh (2020), has discussed customer intentions during the Covid-19 outbreak, in this case in Jordan. Other studies have focused on analysing various factors. Therefore, our study aims to explore customers' intention to use Islamic FinTech during the Covid crisis specifically in Indonesia, which has rarely been discussed by previous researchers.

\subsection{Objective}

The objective of the study is to examine the factors that affect customers' intention to use Islamic FinTech services in Indonesia during the Covid-19 pandemic. The findings are expected to provide deeper understanding of people's intentions to adopt Islamic FinTech, such as payments and peer-to-peer lending, which may benefit practitioners, policymakers, academics, and society. The remainder of the paper is organised as follows. Chapter 2 presents the literature review, Chapter 3 describes the research methodology, while Chapter 4 discusses and analyses the results. Chapter 5 concludes the paper and provides recommendations for further research, together with the limitations of this study.

\section{LITERATURE REVIEW}

\subsection{Background Theory}

\subsubsection{Development of Islamic FinTech in Indonesia}

FinTech constitutes a transformation of the financial system based on new technology. Milian, Spinola \& Carvalho (2019) state that it is a combination of the financial industry, technology, and innovation. Kim, Park, Choi \& Yeon (2015) add that FinTech refers to companies that use technology to increase the efficiency 
of the financial system. This development has caused a shift in the finance and banking industry, in which operational activities are now more technology-driven (Miskam, Yaacob \& Rosman, 2019). According to the World Bank (2020), FinTech services consist of peer-to-peer lending, payment services, market provisioning, crowdfunding equity, analytics and artificial intelligence, wealth management, insurance, amongst others. Based on the data provided by Asosiasi FinTech Indonesia (2018), the highest growth of FinTech services was in peer-to-peer lending, $40 \%$, and payment services, at 34\%.

Alam et al. (2019) explain that the growth of start-ups in the FinTech industry in the form of payments, remittances, digital currencies and others, has been well regulated and overseen by the government because it has created an alternative financial ecosystem available to both customers and businesses. FinTech is also competing with the traditional banking and financial industry in the form of services, products and delivery services.

The development of FinTech triggered the introduction of Islamic FinTech in Indonesia. Ammana was the first Islamic FinTech company and has been operating since 2018. Although Islamic FinTech is relatively new, the services it provides are not significantly different from conventional FinTech, as they both provide financial services. The major difference is the financing contract, as Islamic FinTech needs to follow shariah law. There are three main principles with which Islamic FinTech must comply, namely that it is free of interest (riba), uncertainty (gharar), and gambling (maysir). In Indonesia, Islamic FinTech business is based on MUI No. 67/ DSN-MUI/III/2018, which regulates the provision of the new financial technology institutions (Parizi, 2019). In addition, Islamic FinTech places strong emphasis on three issues, namely ethical values, the real economic sector, and social benefits. Ethical finance with values of transparency, fairness and responsibility is needed to generate MSMEs in Indonesia.

According to Piskin and Kus (2019), the Islamic peer-to-peer lending model is different to that of conventional finance. In Islamic P2P lending, transactions should be based on profit sharing, with several types of contract, such as Al-Ba'i, Ijarah, Mudarabah, Musharakat, Wakalah Bi-I Ujrah, and Qardh. Currently, there are thirteen Islamic FinTech service companies that have been registered with Otoritas Jasa Keuangan (OJK), namely PT. Ammana Fintek Syariah, Alami Sharia, Investree Syariah, PT. Dana Syariah Indonesia, Danakoo Mitra Artha, Qazwa, PT. Duha Madani Syariah, PT. Syarfi Teknologi Finansial, Bsalam, Ethis Indonesia, PT. Berkah Finteck Syariah, Kapital Boost Indonesia, and Papitupi Syariah.

\subsubsection{Technology Acceptance Model}

The technology acceptance model (TAM) was first introduced by Davis (1986) as the most persuasive and robust model in innovation acceptance behaviour. In order to predict the actual usage of new technology, a model construct will normally consist of the variables of perceived ease of use (PEOU) and perceived usefulness (PU) (Lai, 2017). Adams, Nelson \& Todd (1992) later validated the model by exploring validity and reliability measurements for PU and PEOU in different settings and different information systems. After its validation, Straub (1994) and Agarwal and Prasad (1999) extended the model by adding culture, type 
of information system, and task characteristics as moderating effects. In addition, Venkatesh and Davis (1996) also expanded the model by adding external variables, such as social influence, self-efficacy, and other perceptions.

During its development, TAM has been employed by many researchers in various fields, such as mobile wallets (Alaeddin, Rana, Zainudin \& Kamarudin, 2018); e-commerce (Fayad \& Paper, 2015; Fedorko, Bacik \& Gavurova, 2018); e-learning (Ibrahim, Leng, Yusoff, Samy, Masrom \& Rizman, 2017); mobile banking (Aboelmaged \& Gebba, 2013); big data (Okcu, Koksalmis, Basak \& Calisir, 2019); and business-related technologies (Bach, Čeljo \& Zoroja, 2016). Gbongli, Xu \& Amedjonekou (2019) investigated the use of mobile-based money services using the issues of technology anxiety, self-efficacy, perceived ease of use, perceived usefulness, attitude toward mobile money, intention to use mobile money, and personal innovativeness.

In the context of Islamic FinTech services, the technology acceptance model was chosen because it was developed to analyse the use and adoption of new information technology (Davis, 1986). Darmansyah et al. (2020) agree that the latent variables in TAM are the most important factors to determine individuals' intention to use Islamic FinTech in Indonesia. in comparison to the theory of reasoned action (TRA) and the theory of planned behavior (TPB). In TAM, customers' intention is determined by two principles, perceived benefit and perceived ease of use. Perceived benefit is defined as the degree to which people believe that the use of information technology will enhance their job efficiency, while perceived ease of use is defined as the level at which people believe that the use of information technology will be effortless (Venkatesh \& Bala, 2008). The model has been used by some researchers in the field of FinTech (Shaikh et al., 2020; Huei, Cheng, Seong, Khin \& Bin, 2018; Hu, Ding, Li, Chen \& Yang, 2019; Chang, Wong, Lee \& Jeong, 2016; Amalia, 2018; Ichwan \& Kasri, 2019).

\subsection{Previous Studies}

A few studies have been conducted related to consumer acceptance of Islamic FinTech services or Islamic FinTech services (Shaikh et al., 2020; Usman et al., 2020), but the majority have been focused on mobile banking (Elhajjar \& Ouaida, 2019); digital payment (Amalia, 2018); and FinTech (Ichwan \& Kasri, 2019; Niswah, Mutmainah \& Legowati, 2019; Al nawayseh, 2020).

Shaikh et al. (2020) conducted a study of the factors that affect bank customers' acceptance of Islamic FinTech services in Malaysia. 205 sets of data were collected to test the technology acceptance model. Their finding show that perceived usefulness, perceived ease of use, and consumer innovativeness were significant, while self-efficacy and subjective norms were insignificant in influencing such acceptance.

Usman et al. (2020) investigated the relationship between trust, religiosity, image, perceived ease of use, perceived usefulness, and attitude in relation to customer acceptance of FinTech with regard to Islamic philanthropy in Indonesia. 425 sets of data were collected through an online questionnaire and analysed using SEM-PLS to test the application of TAM. The study found that trust and religiosity had a significant relationship with perceived usefulness and perceived 
ease of use, while trust, religiosity, perceived usefulness, perceived ease of use had a significant influence on attitude and intention.

Ichwan and Kasri (2019) conducted a study of the factors that influence millennials to invest in peer-to-peer lending products in Indonesia. 400 sets of data were collected through a questionnaire and analysed using TAM. The finding show that perceived knowledge, trust, and ease of use had a significant relationship with attitude, while attitude had a positive relationship with millennials' intention.

Niswah et al. (2019) examined the factors that influence Muslim millennials' use of FinTech for donations in Indonesia. Data were collected online from 115 respondents and TAM and TPB employed. The study found that perceived behavioural control, subjective norms, and perceived usefulness had a significant influence on behavioural intention, that perceived usefulness and perceived ease of use had an insignificant relationship with attitude, and that attitude had no significant influence on behavioural intention.

Amalia (2018) examined the factors that affect the use of the FinTech digital payment method Paytren using TAM with 199 respondents. The findings show that perceived ease of use and subjective norms had a significant relationship with perceived benefit and perceived ease of use, and that perceived benefit had a significant relationship with attitude.

Elhajjar and Ouaida (2019) examined the factors that influenced the adoption of mobile services in the banking sector in Lebanon using the technology acceptance model. 320 sets of data were collected to measure the relationship between the variables. The results show that perceived risk, digital literacy, resistance to change, perceived ease of use, and perceived usefulness were significant, while awareness and compatability were insignificant.

Current research on customers' intention to use conventional FinTech services during the Covid-19 pandemic has been discussed by Al nawayseh (2020). This study expands the model by using social influence, benefits, technology risks, and trust as independent variables. 500 sets of data from respondents in Jordan were analysed using SEM-PLS. The results show that benefits and social norms significantly affected customers' intention to use FinTech services during the pandemic, while technology risks were found to have no significant affect.

Based on these previous studies, the majority of researchers use perceived ease of use, perceived usefulness, attitude, trust, perceived risk, subjective norms, user knowledge or literacy, and intention as their variables to examine the acceptance of technology. However, no previous research has examined government support for customers' intention to use Islamic FinTech. Therefore, this study expands the TAM method by filling this gap in the literature.

\section{METHODOLOGY}

\subsection{Data}

The primary data for the study were collected through an online platform, with the convenience sampling technique used to select the research sample. This technique is most frequently used in quantitative research (Etikan, Musa \& Alkassim, 2015), including in relation to the topic of the adoption new technology and the issue of the Covid-19 pandemic, such as clinical education in Italy (Fiorino Colombo, Natale, Azzolini, Lagioia \& Danese, 2020). 
The study population comprised Fintech users, and the sample were users of Islamic Fintech payment services and peer-to-peer (P2P) lending; the borrowers had more than 3 months' experience of the services and lived in Jabodetabek ${ }^{1}$ and outside Jabodetabek ${ }^{2}$. According to Kline (2011) and Boomsma and Hoogland (2001), the minimum necessary sample size for SEM to yield good quality result is within the range of 100 to 200. Another study conducted by Anderson and Gerbing (1988) states that the minimum sample to acquire parameter estimates with low standard error is 150. This method was used by Faturohman, Hassandi, and Yulitanti (2020) to investigate the factors influencing customers to use online waqf applications in Indonesia. 220 sets of data, divided into payment and peerto-peer lending customers, were collected to investigate the factors that influence customers' intention to use Islamic FinTech services in Indonesia.

\subsection{Model Development}

According to the literature review, several factors have been used to investigate customers' intention to adopt FinTech, such as perceived ease of use, perceived usefulness, perceived trust, religiosity, image, attitude, subjective norms, and intention (Shaikh et al., 2020; Usman et al., 2020; Ichwan \& Kasri, 2019; Niswah et al., 2019). Al nawayseh (2020) modified the TAM model to analyse factors that affected customers when choosing FinTech applications during the Covid-19 pandemic in Jordan. However, further analysis is required of the relationship between government support during the crisis and customer intention. The application of TAM does not always obtain the same results, as these depend on the variables chosen by researchers and the characteristics of the country studied. Therefore, this study expands the model by adding government support to analyse further customers' intention in the context of the Covid-19 crisis in Indonesia.

The SEM in this study consists of one latent exogenous variable, namely government support, and six latent endogenous variables, namely perceived usefulness, perceived trust, perceived ease of use, user innovativeness, attitude behaviour, and intention. The research framework developed is shown in Figure 1.

1 Jabodetabek refers to Jakarta, Bogor, Depok, Tangerang, and Bekasi

2 Outside Jabodetabek in this study refers to other cities on Java Island 


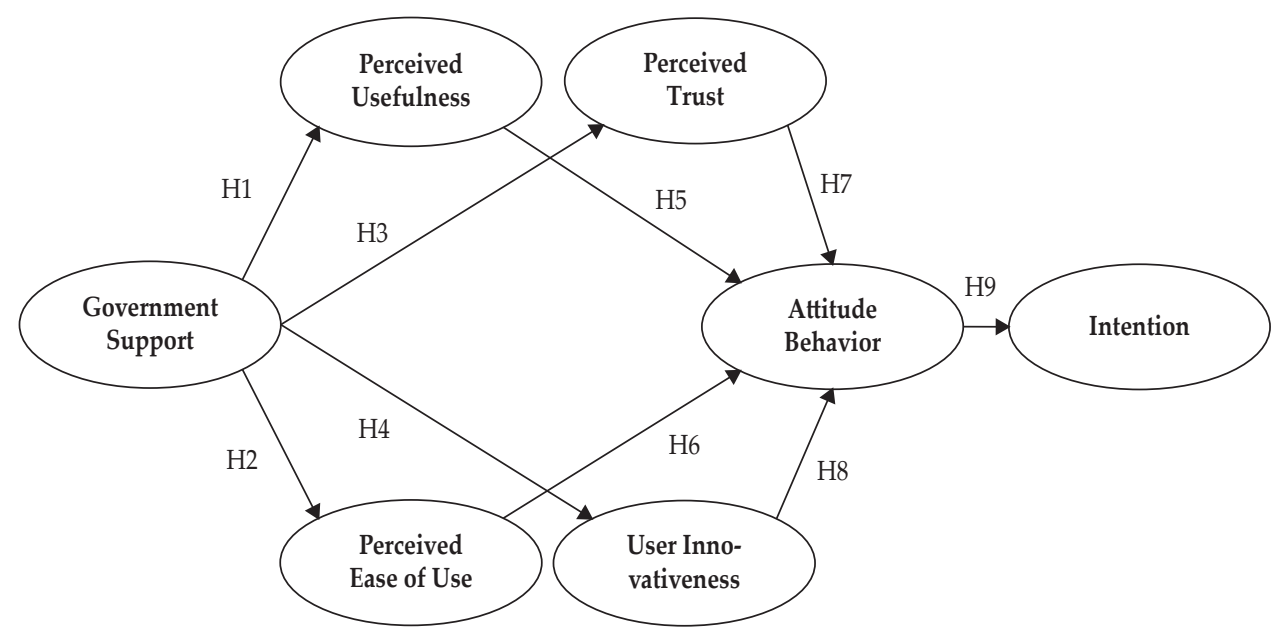

Figure 1.

Model Development of Customer Intention to use Islamic FinTech in Indonesia and Hypothesis Testing

According to Park, Kim \& Forney (2006), government support is considered to be an external factor that plays an important role in introducing new technology. Yoon, Guimaraes \& O’Neal (1995) also state that government support can be varied, such as financial guidance, imposition of new regulations, fiscal and tax policies, and infrastructure, amongst others. In addition, Wang and Chen (2012) state that proactive governments will influence individuals' perception that they exist to support a particular system. The empirical study conducted by Al Haderi (2014) found that government support has a positive impact on individuals' perceived usefulness if they belief that the technology will provide benefits for them. Riquelme and Rios (2010) also explain that customers will think new technology is convenient and easy to use if the government introduces regulations to support its implementation. In the context of Islamic FinTech, government support, such as good infrastructure, regulation, and continuous programmes, will make people think that Islamic FinTech services are friendly and easy to use, enhance their job performance and provide benefits. Therefore, the following hypotheses are proposed:

H1: Government support has a positive and significant impact on perceived usefulness during the Covid-19 pandemic.

H2: Government support has a positive and significant impact on perceived ease of use during the Covid-19 pandemic.

Trust is a major concern regarding the implementation of new systems or technology in a country. Parent, Vandebeek \& Gemino (2005) divided trust into two categories, namely that in the mechanism (technology) and that in the entity (government) that provide services. In addition, Lin and Ho (2009) argue that government intervention can either encourage the implementation of new 
technology or hinder the process. When people believe that the government will provide good support for new technology, they will be more likely to use it (Chong, Ooi, Lin \& Tan, 2010). In the field of banking, Marakarkandy, Yajnik \& Dasgupta (2017) conducted a study of the factors that affect customer use of online banking. They found that government support, such as regulation and infrastructure, had a significant effect on customer trust. In the context of Islamic FinTech, customers will have trust in government support if it provides security that protects the system (Grabner-Krauter \& Faullant, 2008). This support would be very important during times of crisis where the economy is not stable. Therefore, it is proposed that:

H3: Government support has a positive and significant impact on trust during the Covid-19 pandemic.

According to Khalil (2000), a country need innovation in order to be more competitive than others, while Handoko, Smith \& Burvill (2014) found that government plays an important role in the process of transferring knowledge and technology to SME innovativeness in Indonesia. Kemmis (2004) and Rogers (2003) state that an important stage in the transfer process is the ability to adapt to new technology. In the context of Islamic FinTech, when the government supports digitalisation during the Covid-19 pandemic, people will learn to adapt to the new conditions and concentrate more on online systems (Arora, Charm, Grimmelt, Ortega, Robinson, Sexauer \& Yamakawa, 2020). Therefore, the related hypothesis posited is:

H4: Government support has a positive and significant impact on user innovativeness during the Covid-19 pandemic.

According to Davis et al. (1989), perceived ease of use refers to the level of customers' perception that new technology is user friendly, while perceived usefulness refers to their level of perception of the use of new technology in improving job performance (Kim, Choi, Park \& Yeon, 2016). If customers believe that FinTech services are easy to use, they will be more likely to feel the benefits of using them and will have a positive attitude towards such services (Garay, Font \& Corrons, 2019). Numerous studies have found a positive correlation between both perceived ease of use and perceived usefulness and attitude towards new technology, such as online banking (Boateng, Adam, Okoe \& Anning-Dorson, 2016; Szopiński, 2016; Montazemi \& Qahri-Saremi, 2015); FinTech services (Huei et al., 2018; Hu et al., 2019; Jin, Seong \& Khin, 2019); and Islamic FinTech (Shaikh et al., 2020). Therefore, it is proposed that:

H5: Perceived usefulness has a positive and significant impact on attitude behaviour to adopt Islamic FinTech during the Covid-19 pandemic. H6: Perceived ease of use has a positive and significant impact on attitude behaviour to adopt Islamic FinTech during the Covid-19 pandemic. 
Numerous empirical studies have also found that trust play an important role in shaping the attitudes of potential users towards using a new technology. In the context of mobile banking adoption, Hanafizadeh, Behboudi, Koshksaray \& Tabar (2014) found that perceived trust had a significant relationship with the attitude of customers towards using mobile banking services, while Mahad, Mohtar \& Othman (2015) made similar findings. Their study agreed that users' perceived trust had a significant effect on user attitude. In the context of FinTech services, Hu et al. (2019) underline that user trust has a significant relationship with attitudes regarding the adoption of FinTech services. The following hypothesis is therefore proposed:

H7: Perceived trust has a positive and significant impact on attitude behaviour to adopt Islamic FinTech during the Covid-19 pandemic.

User innovativeness refers to the level of early adoption of new technology. If people are highly innovative, they will have more interest and intention to try new products and technology (Leicht, Chtourou, \& Youssef, 2018). Since Islamic FinTech services are a new introduction, individual innovation plays an important role in affecting attitude. Kim, Mirusmonov \& Lee (2010) agreed that when mobile services were launched, people's innovation reflected their attitude. Therefore, it is posited that:

H8: User innovativeness has a positive and significant impact on attitude behaviour to adopt Islamic FinTech during the Covid-19 pandemic.

According to Sekhon, Sunikka, Peura-Kapanen \& Raijas (2010), when users have a positive attitude towards new technology, they will be more likely to have a strong intention to display a specific behaviour. Gupta and Arora (2017) found that customers' attitude had a positive effect on their intention to adopt mobile banking in India. Hu et al. (2019) agreed that the attitude of customers in China had a significant and positive impact on their intention to use FinTech services. Therefore, the associated hypothesis put forward is:

H9: Attitude behaviour has a positive and significant impact on the intention to adopt Islamic FinTech during the Covid-19 pandemic.

\subsection{Measurement}

In order to achieve the research objectives, a questionnaire was constructed and primary data were collected through an online platform to obtain meaningful results. The questionnaire was divided into three parts: the first part asked screening questions; the second part established the respondents' profile; and the third part examined the variables using a five-point Likert scale, from strongly disagree (1), disagree (2), neutral (3), agree (4), to strongly agree (5). The structure of the questionnaire is shown in Table 1. 
Table 1.

Questionnaire Items

\begin{tabular}{|c|c|c|c|}
\hline Variable & Code & Items & Sources \\
\hline \multirow{4}{*}{$\begin{array}{l}\text { Government } \\
\text { Support (GS) }\end{array}$} & GS1 & $\begin{array}{l}\text { The government provides infrastructure to } \\
\text { support the use of Islamic FinTech services, } \\
\text { such as telecom networks. }\end{array}$ & \multirow{4}{*}{$\begin{array}{l}\text { Hu et al. (2019); } \\
\text { Marakarkandy et } \\
\text { al. (2017) }\end{array}$} \\
\hline & GS2 & $\begin{array}{l}\text { The government has introduced regulations } \\
\text { to support Islamic FinTech services. }\end{array}$ & \\
\hline & GS3 & $\begin{array}{l}\text { Government support could improve the use } \\
\text { of Islamic FinTech services. }\end{array}$ & \\
\hline & GS4 & $\begin{array}{l}\text { The government provides programs to } \\
\text { support Islamic FinTech services. }\end{array}$ & \\
\hline \multirow{5}{*}{$\begin{array}{l}\text { Perceived } \\
\text { Usefulness (PU) }\end{array}$} & PU1 & Islamic FinTech services can meet my needs. & \multirow{5}{*}{$\begin{array}{l}\text { Fedorko et al. } \\
\text { (2018); Hu et al. } \\
\text { (2019); Lockett } \\
\text { and Littler. (1997); } \\
\text { Huh et al. (2009) }\end{array}$} \\
\hline & PU2 & $\begin{array}{l}\text { Transactions using Islamic FinTech services } \\
\text { can save time efficiently. }\end{array}$ & \\
\hline & PU3 & $\begin{array}{l}\text { Islamic FinTech services can improve } \\
\text { efficiency. }\end{array}$ & \\
\hline & PU4 & $\begin{array}{l}\text { Islamic FinTech services makes it easy to } \\
\text { manage my financial activities. }\end{array}$ & \\
\hline & PU5 & $\begin{array}{l}\text { Overall, Islamic FinTech services are useful } \\
\text { for me. }\end{array}$ & \\
\hline \multirow{4}{*}{$\begin{array}{l}\text { Perceived Ease of } \\
\text { Use (PE) }\end{array}$} & PE1 & $\begin{array}{l}\text { The applications and websites are friendly } \\
\text { and understandable. }\end{array}$ & \multirow{4}{*}{$\begin{array}{l}\text { Hu et al. (2019); } \\
\text { - Wang, Wang, Lin } \\
\text { \& Tang (2014) }\end{array}$} \\
\hline & PE2 & $\begin{array}{l}\text { The applications and websites are very easy } \\
\text { to use. }\end{array}$ & \\
\hline & PE3 & $\begin{array}{l}\text { The applications and websites are very easy } \\
\text { to operate. }\end{array}$ & \\
\hline & PE4 & $\begin{array}{l}\text { The applications and websites require little } \\
\text { effort. }\end{array}$ & \\
\hline \multirow{4}{*}{$\begin{array}{l}\text { Perceived Trust } \\
\text { (PT) }\end{array}$} & PT1 & $\begin{array}{l}\text { The companies that manage Islamic FinTech } \\
\text { services are honest, and keep their promises } \\
\text { and obligations. }\end{array}$ & \multirow{4}{*}{$\begin{array}{l}\text { - Usman el al. } \\
(2020)\end{array}$} \\
\hline & PT2 & $\begin{array}{l}\text { The companies that manage Islamic FinTech } \\
\text { services provide secure privacy. }\end{array}$ & \\
\hline & PT3 & $\begin{array}{l}\text { The information provided by the companies } \\
\text { that manage Islamic FinTech services are } \\
\text { reliable. }\end{array}$ & \\
\hline & PT4 & $\begin{array}{l}\text { The information provided by the companies } \\
\text { that manage Islamic FinTech services meet } \\
\text { my needs. }\end{array}$ & \\
\hline \multirow{5}{*}{$\begin{array}{l}\text { User } \\
\text { Innovativeness } \\
\text { (UI) }\end{array}$} & UI1 & $\begin{array}{l}\text { Compared to my peers, I would be the first } \\
\text { to experiment with new technologies. }\end{array}$ & \multirow{5}{*}{ Turan et al. (2015) } \\
\hline & UI2 & I would like to explore new technologies. & \\
\hline & UI3 & $\begin{array}{l}\text { I would like to look for more information } \\
\text { about new technologies. }\end{array}$ & \\
\hline & UI4 & $\begin{array}{l}\text { I have high expectations about the } \\
\text { performance of the new systems I use. }\end{array}$ & \\
\hline & UI5 & I usually easily adapt to new technologies. & \\
\hline
\end{tabular}


Table 1.

Questionnaire Items (Continued)

\begin{tabular}{|c|c|c|c|}
\hline Variable & Code & Items & Sources \\
\hline \multirow{4}{*}{$\begin{array}{l}\text { Attitude } \\
\text { Behaviour (AB) }\end{array}$} & AB1 & $\begin{array}{l}\text { I have pleasant experiences using Islamic } \\
\text { FinTech services. }\end{array}$ & \multirow{4}{*}{$\begin{array}{l}\text { Hu et al. (2019); } \\
\text { Grabner \& } \\
\text { Faullant. (2008) }\end{array}$} \\
\hline & $\mathrm{AB} 2$ & I am interested in Islamic FinTech services. & \\
\hline & AB3 & $\begin{array}{l}\text { I believe using Islamic FinTech services is a } \\
\text { good idea. }\end{array}$ & \\
\hline & $\mathrm{AB} 4$ & $\begin{array}{l}\text { I like to be informed about news from } \\
\text { Islamic FinTech companies. }\end{array}$ & \\
\hline \multirow{5}{*}{ Intention (INT) } & INT1 & $\begin{array}{l}\text { If I have used Islamic FinTech services, I am } \\
\text { willing to continue using them. }\end{array}$ & \multirow{5}{*}{ Hu et al. (2019) } \\
\hline & INT2 & $\begin{array}{l}\text { I will recommend Islamic FinTech services to } \\
\text { my friends. }\end{array}$ & \\
\hline & INT3 & $\begin{array}{l}\text { I will use Islamic FinTech services in the near } \\
\text { future. }\end{array}$ & \\
\hline & INT4 & $\begin{array}{l}\text { I presently intend to use Islamic FinTech } \\
\text { services. }\end{array}$ & \\
\hline & INT5 & $\begin{array}{l}\text { I intend to use Islamic FinTech services to } \\
\text { increase convenience. }\end{array}$ & \\
\hline
\end{tabular}

\subsection{Method}

Following previous research, the method used in this study was a quantitative approach using a questionnaire. The study variables consisted of government support, perceived usefulness, perceived ease of use, perceived trust, user innovativeness, attitude, and intention to adopt Islamic FinTech. The data were analysed using PLS-SEM (partial least squares - structured equation modelling). This statistical software has been used in various fields, such as marketing, business, and management (Hair, Ringle \& Sarstedt, 2013). PLS path modelling is used to examine the direct and indirect effects of independent variables on the dependent variable.

Based on Figure 2, path analysis is used to measure the indirect effect of government support on attitude behaviour. Six paths were examined in the structural model:

$$
\begin{aligned}
& P U=11^{*} \mathrm{GS}+C_{1} \\
& P E=21^{*} \mathrm{GS}+C_{2} \\
& P T=31^{*} \mathrm{GS}+C_{3} \\
& U I=41^{*} \mathrm{GS}+C_{4} \\
& \mathrm{AB}=\beta 51^{*} \mathrm{PU}+\beta 52^{*} \mathrm{PE}+\beta 53^{*} \mathrm{PT}+\beta 54^{*} \mathrm{UI}+C_{5} \\
& I N T=\beta 55^{*} \mathrm{AB}+C_{6}
\end{aligned}
$$


where:

$\begin{array}{ll}\text { GS } & \text { : Government Support } \\ \text { PE } & \text { : Perceived Ease of Use } \\ \text { PU } & \text { : Perceived Usefulness } \\ \text { PT } & \text { : Perceived Trust } \\ \text { UI } & \text { : User Innovativeness } \\ \text { AB } & \text { : Attitude Behaviour } \\ \text { INT } & \text { : Intention } \\ \text { C } & \text { : Error }\end{array}$

In order to obtain the results, the analysis comprised several steps. In the first step, the study used SEM-PLS for the goodness of fit of model (R-squared), a reliability and validity test (Cronbach's alpha, rho_A, composite reliability, AVE), and a collinearity test (VIF). Instead of using Cronbach's alpha, some previous researchers have used composite reliability because both tests are based on a similar interpretation that 0.7 and above is considered to be very good (Ursachi, Horodnic, \& Zait, 2015). VIF is used to check for multicollinearity. If the value exceeds the threshold of 4 , the model has a correlated independent problem or multicollinearity problem (Hair, Black, Babin \& Anderson, 2010). Moreover, the study conducted by Ascarya and Rahmawati (2018) indicates that each indicator can be considered to be very significant if the value of the standardised loading factor is above 0.5 .

In the second step, the bootstrapping technique was employed to test the hypothesis based on path modelling (Hair, Ringle \& Sarstedt, 2011). A two-tailed test was used at a significance level of 5 percent. In the final step, an analysis of the descriptive statistics was conducted to illustrate the demographic and other selected characteristics of the respondents.

\section{RESULTS AND ANALYSIS}

\subsection{Results}

\subsubsection{Profile of the Respondents}

As shown in Table 2, 69.5\% of the respondents were male and 30.5\% were female. The majority, $44.5 \%$, were in the age range $29-39$, followed by $29.5 \%$ in the age range $40-50.17 \%$ were peer-to-peer lending users and $83 \%$ payment service users. In terms of occupation, $68.2 \%$ were private employees and $26.8 \%$ entrepreneur. $67.3 \%$ were from Jabodetabek ${ }^{3}$, while $32.7 \%$ were from outside Jabodetabek ${ }^{4}$. Monthly income was dominated by the level between Rp5.000.001 - Rp7.500.000, at $44.5 \%$.

\footnotetext{
3 Jabodetabek refers to Jakarta, Bogor, Depok, Tangerang and Bekasi

4 Outside Jabodetabek in this research refers to other cities on Java Island.
} 
Table 2.

Respondent Profile

\begin{tabular}{|c|c|c|c|}
\hline \multicolumn{2}{|c|}{ Demographic Variables } & \multirow{2}{*}{$\begin{array}{c}\text { Frequency } \\
153\end{array}$} & \multirow{2}{*}{$\begin{array}{c}\text { Percent } \\
69.5\end{array}$} \\
\hline Cender & Male & & \\
\hline Gender & Female & 67 & 30.5 \\
\hline \multirow{4}{*}{ Age } & $18-28$ & 20 & 9.1 \\
\hline & $29-39$ & 120 & 54.6 \\
\hline & $40-50$ & 65 & 29.5 \\
\hline & $>50$ & 15 & 6.8 \\
\hline \multirow{4}{*}{ Education } & Senior High School & 20 & 9.1 \\
\hline & Bachelor's Degree & 132 & 60.0 \\
\hline & Master's Degree & 66 & 30.0 \\
\hline & Doctoral Degree & 2 & 0.9 \\
\hline \multirow{4}{*}{ Occupation } & Private Employee & 151 & 68.2 \\
\hline & Civil Servant & 6 & 2.7 \\
\hline & Entrepreneur & 59 & 26.8 \\
\hline & Other & 5 & 2.3 \\
\hline \multirow[b]{2}{*}{ Region } & Jabodetabek & 148 & 67.3 \\
\hline & Outside Jabodetabek & 72 & 32.7 \\
\hline \multirow{4}{*}{ Monthly Income } & Rp2.500.000 - Rp5.000.000 & 91 & 41.5 \\
\hline & Rp5.000.001 - Rp7.500.000 & 98 & 44.5 \\
\hline & $\begin{array}{l}\text { Rp7.500.001 - } \\
\text { Rp10.000.000 }\end{array}$ & 25 & 11.2 \\
\hline & Above Rp10.000.000 & 6 & 2.8 \\
\hline
\end{tabular}

The results also show that $86 \%$ of the respondents knew about the services offered by Islamic FinTech, while $14 \%$ were not aware of them. $80 \%$ of the respondents had used Islamic FinTech services such as apps and websites, while $20 \%$ had not done so. In the case of customers' understanding of the differences between Islamic and conventional FinTech, $69 \%$ of the respondents knew and understood the differences, while the remainder did not.

\subsubsection{Reliability and Validity Test}

The results of the reliability test can be seen in Table 3, which shows that Cronbach's alpha coefficient is between 0.5 and 0.9. According to Hulland (1999), a value of 0.4 or higher is acceptable for exploratory research, while a value of 0.7 or higher is preferred. Barclay, Higgins and Thompson (1995) added that the interpretation of composite reliability should be similar to Cronbach's alpha, with values of 0.7 and above considered to be very good. In this study the value was above 0.8 . 
Table 3.

Reliability and Validity

\begin{tabular}{lcccc}
\hline Variable & $\begin{array}{c}\text { Cronbach's } \\
\text { Alpha }\end{array}$ & rho_A & $\begin{array}{c}\text { Composite } \\
\text { Reliability }\end{array}$ & AVE \\
\hline Attitude Behaviour (AB) & 0,872 & 0,875 & 0,914 & 0,726 \\
Government Support (GS) & 0,831 & 0,837 & 0,889 & 0,669 \\
Intention (INT) & 0,832 & 0,834 & 0,882 & 0,599 \\
Perceived Ease of Use (PEU) & 0,851 & 0,873 & 0,901 & 0,699 \\
Perceived Trust (PT) & 0,730 & 0,735 & 0,832 & 0,556 \\
Perceived Usefulness (PU) & 0,870 & 0,877 & 0,906 & 0,659 \\
User Innovativeness (UI) & 0,861 & 0,865 & 0,900 & 0,644 \\
\hline
\end{tabular}

In addition, the average variance extracted (AVE) value is convergent validity is used to measure the variance explained by the items compared to that due to measurement error. The value of AVE should be 0.5 and above (Fornell \& Larcker, 1981). Therefore, it can be concluded that the latent variable used in this study fulfils the requirement for reliability and validity and that the results are at level of reliability and consistency, and are valid.

\subsubsection{Multicollinearity Test}

The VIF results can be seen in Table 4. Hair et al. (2010) state that a common threshold for VIF is 10, while Kline (1998) states that its maximum value is 5. Based on the results, it can be seen that the study passed the multicollinearity test.

Table 4.

Collinearity Assessment (VIF)

\begin{tabular}{|c|c|c|c|c|c|c|c|}
\hline & $\mathrm{AB}$ & GS & INT & $\mathrm{PE}$ & PT & PU & UI \\
\hline $\mathrm{AB}$ & & & 1,000 & & & & \\
\hline GS & & & & 1,000 & 1,000 & 1,000 & 1,000 \\
\hline \multicolumn{8}{|c|}{ INT } \\
\hline PE & 3,931 & & & & & & \\
\hline PT & 3,638 & & & & & & \\
\hline PU & 4,527 & & & & & & \\
\hline UI & 4,158 & & & & & & \\
\hline
\end{tabular}

\subsubsection{Structural Model}

Goodness test fit in PLS was based on the value of R-squared, as shown in Table 4. It is used to measure the strength between two or more variables. The higher the coefficient, the closer the relationship between the variables. According to Wong (2013), an R-squared value of 0.75 is considered to be substantial, 0.50 is considered as moderate, and 0.25 weak. Based on the results shown in Table 5, the R-squared value of 0.613 for intention can be considered to be good. This means that the five latent variables (PE, PU, PT, UI, and $\mathrm{AB}$ ) moderately explain $61.3 \%$ of the variance 
in the intention to use. In addition, the conceptual model explains $74.6 \%$ of the variance in attitude, $63.9 \%$ of the variance in perceived ease of use, $58.8 \%$ of the variance in perceived usefulness, $54.5 \%$ of the variance in user innovativeness, and $46.3 \%$ of the variance in perceived trust.

Table 5.

R-Squared

\begin{tabular}{lc}
\hline Variable & R-Squared \\
\hline Attitude Behaviour & 0,746 \\
Intention & 0,613 \\
Perceived Ease of Use & 0,639 \\
Perceived Trust & 0,463 \\
Perceived Usefulness & 0,588 \\
User Innovativeness & 0,544 \\
\hline
\end{tabular}

Table 6.

Hypothesis Testing

\begin{tabular}{lcccccc}
\hline Hypothesis & $\begin{array}{c}\text { Original } \\
\text { Sample } \\
(\mathbf{O})\end{array}$ & $\begin{array}{c}\text { Sample } \\
\text { Mean } \\
(\mathbf{M})\end{array}$ & $\begin{array}{c}\text { Standard } \\
\text { Deviation } \\
\text { (STDEV) }\end{array}$ & $\begin{array}{c}\text { T Statistics } \\
(\mid \text { O/STDEV } \mid)\end{array}$ & $\begin{array}{c}\mathbf{P} \\
\text { Value }\end{array}$ & Decision \\
\hline GS -> PU & 0,767 & 0,767 & 0,037 & 20,671 & 0,000 & Accepted \\
GS -> PE & 0,799 & 0,801 & 0,034 & 23,780 & 0,000 & Accepted \\
GS -> PT & 0,681 & 0,685 & 0,037 & 18,222 & 0,000 & Accepted \\
GS -> UI & 0,737 & 0,737 & 0,040 & 18,514 & 0,000 & Accepted \\
PU -> AB & 0,431 & 0,434 & 0,091 & 4,756 & 0,000 & Accepted \\
PE -> AB & 0,331 & 0,327 & 0,088 & 3,764 & 0,000 & Accepted \\
PT - AB & 0,107 & 0,112 & 0,058 & 1,835 & 0,067 & Rejected \\
UI -> AB & 0,052 & 0,049 & 0,090 & 0,573 & 0,567 & Rejected \\
AB -> INT & 0,783 & 0,783 & 0,034 & 22,979 & 0,000 & Accepted \\
\hline
\end{tabular}

Hypothesis 1: Government support has a positive and significant impact on perceived usefulness during the Covid-19 pandemic.

Based on Table 6, the findings show that there was a positive and significant relationship between government support (GS) and perceived usefulness (PU), with the p-value less than or equal to the alpha $(\boldsymbol{\alpha})$ or $0.000 \leq 0.05$, meaning H1 is accepted.

Hypothesis 2: Government support has a positive and significant impact on perceived ease of use during the Covid-19 pandemic.

There was a positive and significant relationship between government support (GS) and perceived ease of use (PE), with the p-value less than or equal to the alpha $(\alpha)$ or $0.000 \leq 0.05$, so $\mathrm{H} 2$ is accepted.

Hypothesis 3: Government support has a positive and significant impact on trust during the Covid-19 pandemic. 
There was a positive and significant impact of government support (GS) on perceived trust (PT), with the p-value less than or equal to the alpha $(\boldsymbol{\alpha})$ or $0.000 \leq$ 0.05 , therefore $\mathrm{H} 3$ is acccepted.

Hypothesis 4: Government support has a positive and significant impact on user innovativeness during the Covid-19 pandemic.

There was a positive and significant impact of government support (GS) on user innovativeness (UI), with the p-value less than or equal to the alpha $(\boldsymbol{\alpha})$ or $0.000 \leq 0.05$, meaning $\mathrm{H} 4$ is accepted.

Hypothesis 5: Perceived usefulness has a positive and significant impact on attitude behaviour to adopt Islamic FinTech during the Covid-19 pandemic.

There was a positive and significant relationship between perceived usefulness $(\mathrm{PU})$ and attitude behaviour $(\mathrm{AB})$, with the p-value less than or equal to the alpha $(\boldsymbol{\alpha})$ or $0.000 \leq 0.05$, so $\mathrm{H} 5$ is accepted. This finding is in line with the study of $\mathrm{Hu}$ et al. (2019).

Hypothesis 6: Perceived ease of use has a positive and significant impact on attitude behaviour to adopt Islamic FinTech during the Covid-19 pandemic.

There was a positive and significant relationship between perceived ease of use (PE) and attitude behaviour (AB). with the p-value less than or equal to the alpha $(\alpha)$ or $0.000 \leq 0.05$, so H6 is accepted. This finding is in line with an empirical study conducted by Shaikh et al. (2020), who found that perceived ease of use was one of the main factors that motivated customers to use Islamic FinTech services in Malaysia.

Hypothesis 7: Perceived trust has a positive and significant impact on attitude behaviour to adopt Islamic FinTech during the Covid-19 pandemic.

Perceived trust (PT) was found to have an insignificant impact on attitude behaviour $(\mathrm{AB})$, with a p-value higher than alpha $(\alpha)$, or $0.067>0.05$, so H7 was rejected, although it was statistically significant at the level of $99 \%$.

Hypothesis 8: User innovativeness has a positive and significant impact on attitude behaviour to adopt Islamic FinTech during the Covid-19 pandemic.

User innovativeness (UI) was found to have an insignificant impact on attitude behaviour $(\mathrm{AB})$, with the $\mathrm{p}$-value higher than alpha $(\alpha)$ or $0.567>0.05$, so H8 was also rejected.

Hypothesis 9: Attitude behaviour has a positive and significant impact on intention to adopt Islamic FinTech during the covid-19 pandemic.

There was a positive and significant relationship between attitude behaviour (AB) and intention (INT), with the p-value less than or equal to the alpha $(\boldsymbol{\alpha})$, or $0.000 \leq 0.05$. Therefore, $\mathrm{H} 9$ is supported to explain intention. 


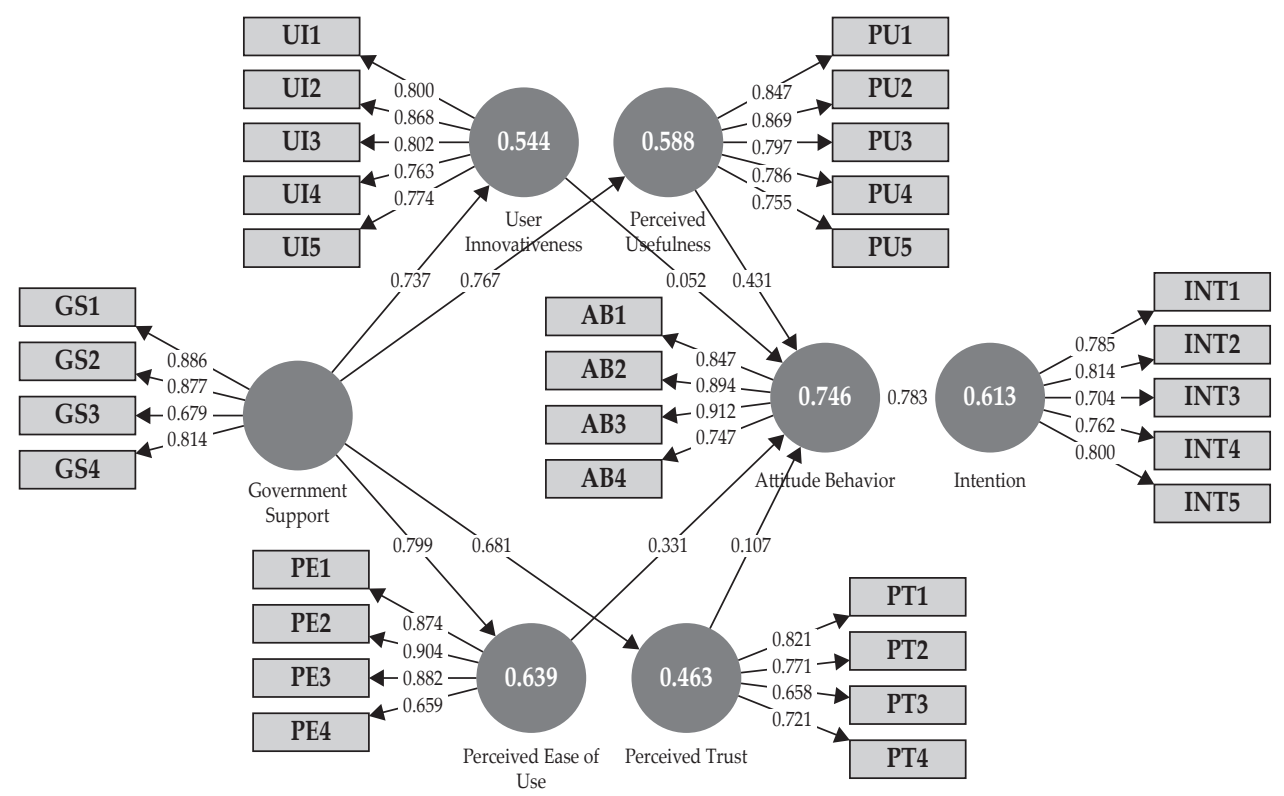

Figure 2.

Outer Loadings

As shown in Figure 2, all the measured variables (GS1 - GS4) significantly explain government support. GS2 (The government has introduced regulations to support Islamic FinTech services) has the highest loading factor of 0.877 , followed by GS1 (The government provides infrastructure to support the use of Islamic FinTech services, such as telecom networks) at 0.886 and GS4 (The government provides programs to support Islamic FinTech services), at 0.814 .

All the measured variables (PE1 - PE4) significantly explain perceived ease of use. PE2 (The application and website are very easy to use) has the highest loading factor of 0.904 , followed by PE1 (The application and website are user-friendly and understandable) at 0.874 and PE3 (The application and website are very easy to operate) at 0.882 .

All the measured variables (UI1 - UI5) significantly explain user innovativeness. UI2 (I would like to explore new technologies) has the highest loading factor of 0.868 , followed by UI3 (I would like to look for more information about new technologies) at 0.802 and UI1 (Compared to my peers, I would be the first to experiment with new technologies) at 0.800 .

All measured variables (PU1 - PU5) significantly explain perceived usefulness. PU2 (Transactions using Islamic FinTech services can save time efficiently) has the highest loading factor of 0.869 , followed by PU1 (Islamic FinTech services can meet my needs) at 0.847 .

All the measured variables (PT1 - PT4) significantly explain perceived trust. PT1 (Companies that manage Islamic FinTech services are honest, and keep their promises and obligations) has the highest loading factor of 0.821 .

All the measured variables (AB1 - AB4) significantly explain attitude behaviour. AB3 (I believe using Islamic FinTech services is a good idea) has the 
highest loading factor of 0.912 , followed by AB2 (I am interested in Islamic FinTech services) at 0.894 and AB1 (I have a pleasant experience when using Islamic FinTech services) at 0.847.

All the measured variables (INT1 - INT5) significantly explain intention. INT2 (I will recommend Islamic FinTech services to my friends) at 0.814 has the highest loading factor, followed by INT5 (I intend to use Islamic FinTech services to increase convenience) at 0.800 .

\subsection{Analysis}

During the Covid-19 pandemic, government support in Indonesia has encouraged customers to try and implement new technologies. The regulations imposed by the government related to physical and social distancing encourage society to easily adapt to the new environment, in which the majority of activities need to be based on online, such as online shopping, online teaching, and online business through e-commerce. Although shifting to online systems is challenging for some people, the situation has actually transformed their ability to embrace the new technology (Stanciu, Radu, Sapira, Bratoveanu \& Florea, 2020). Government support in the form of regulations, infrastructure, funding and programs during the pandemic has been found to have a significant and positive impact on customers' perceived ease of use, perceived usefulness, perceived trust, and user innovativeness.

Government support during the pandemic has encouraged Islamic FinTech companies to provide services based on customers' needs and expectations, although social distancing limits face-to-face services between customers, investors, and FinTech companies. This finding is in line with the study of $\mathrm{Hu}$ et al. (2019). Natalia (2020) adds that all technology-based financial services, including digital payment systems, digital financial innovation (IKD), online loans, equity crowdfunding (ECF), and other FinTech solutions, have continued to run normally during the Covid-19 pandemic because of the nature of the business that supports digitalisation. Islamic FinTech services are also known for their easy processes, ease of operation, user-friendliness for new users, and they require little effort. The degree of ease in using the apps and website of Islamic FinTech services is very important at this time. The findings of this study show that government support during Covid-19 has had an impact on customers' trust. The data provided by Asosiasi FinTech Indonesia (AFTECH) shows that FinTech payments have helped individuals and MSMEs to make transactions during social distancing. In addition, the data from the Rapyd (2020) regarding Asia Pacific E-commerce and Payment Guide, 2020 shows that the transactions using ATMs and debit cards fell to around 450 million in April compared to 550 million in March 2020. This shows that there were changes in customer behaviour and that trust in FinTech services grew compared to traditional services during the Covid-19 crisis. This new finding adds to the literature and contributes to the understanding of customers' perceptions of the role of government support in developing Islamic FinTech services.

User innovativeness in this study indicates how easily and quickly customers can adapt to new technology compared to their peers. According to Turan, Tunc \& Zehir (2015), the successful implementation of new technology depends on individuals' ability to adopt to new technology. Another empirical study conducted 
by Darmansyah et al. (2020) supports the view that the use of technology has had a significant effect on customers' intention to use Islamic FinTech services in Indonesia. The more people are exposed to technology, the greater their intention to use FinTech services. In addition, the features of security and user-friendliness in FinTech also increase customers' intention to use the services, and which become part of their daily activities.

In terms of attitude behaviour, the variables of perceived ease of use and perceived usefulness were found to have a significant and positive impact, while perceived trust and user innovativeness were found to have no significant impact during the Covid-19 crisis. This is due to two factors. First, the lack of financial literacy that may hinder the application of Islamic FinTech services. Pratama (2020) states that only $69 \%$ of the Indonesian population are banked, while $51 \%$ of them are unbanked. Although government promotes the application of Islamic and conventional FinTech services to all levels of businesses in Indonesia, the development of technology has helped many irresponsible people to easily create applications and websites which are targeted towards unbanked people with low financial literacy who need money to meet basic short-term needs or consumption. Even now, illegal FinTech also uses social media to text messages, which offer loans at high interest. This issue has affected customers' perception of trust. Therefore, in order to increase financial inclusion during the Covid-19 pandemic, support from the regulatory side is still needed to ensure optimal growth in the FinTech industry.

The second reason is the lack of digital literacy. The Covid-19 pandemic has lent more urgency to the modernisation of Government to Person (G2P) payments in Indonesia, especially using FinTech services. However, the adoption of Islamic FinTech for G2P payments is still limited (Asosiasi FinTech Indonesia, 2020). The use of cards and the distribution of physical assistance continue to dominate the distribution of government assistance to the community during the COVID-19 period. In addition, some micro, small, and medium enterprises lack the ability to adapt to the changes in technology. In other words, although the government provides infrastructure and systems to promote Islamic FinTech services, the use of these varies based on customers' willingness to adapt to the new technology, their education level and occupation. This empirical finding makes a new contribution to the field of Islamic FinTech services, filling the gap between previous studies and practice.

\section{CONCLUSION AND RECOMMENDATIONS}

\subsection{Conclusion}

The purpose of this study was to investigate the factors that have affected customers' intention to use Islamic FinTech services during the Covid-19 pandemic. The Securities Commission of Malaysia (2020) states that the emergence of Islamic FinTech offers opportunities for unbanked users with very low financial literacy and MSMEs to have better and more sustainable lives and business in the future. Hudaefi (2020) adds that Islamic FinTech also promotes social finance through waqf, zakat, and infaq, being able to promote the sustainable development goals of reducing inequality and ending poverty and hunger. 
Based on the results, government support for Islamic FinTech, which consists of partnership strategies between Islamic finance and Islamic FinTech companies, physical and digital infrastructure, regulation, and inclusion and literacy programs, has had an indirect impact on attitude behaviour to use Islamic services through perceived ease of use and perceived usefulness. Attitude behaviour was found to have an impact on intention. However, user innovativeness and perceived trust were found to have no impact on attitude behaviour.

\subsection{Recommendations}

Islamic FinTech services, as an alternative to increasing financial inclusion, need cooperation between Islamic FinTech companies, the government, banks, and customers. This study has several implications for Islamic FinTech companies. The findings can be used as a reference for practitioners to prioritise strategy based on customer intent during the Covid-19 crisis. Although perceived trust and user innovativeness were found to have no significant on customers' intention to use Islamic FinTech services, FinTech companies still have an opportunity to dominate the huge market of unbanked people by offering transparent products and userfriendly features.

Probst (2020) states that transparency can increase users' trust in digital technology. In addition, Bourne (2019) elaborates that transparency in financial products means clear information is provided to the public about product features, risks of investments, prices, fairness, and unquestioned business principles. Wang et al. (2014) agree that the open programs and activity will increase customers' willingness to continue in using FinTech services. Birchall (2011) adds that during the crisis, transparency should be a main feature of the culture and morals of companies. One of the ways to increase transparency is to utilise marketing tools, such as social media promotion, website navigation, search engine optimisation, or real feedback from public figures or current customers. In this way, any lack of customer trust will be reduced and the issue of illegal FinTech companies could also be diminished.

Islamic FinTech companies could also make marketing campaigns, such as offering rewards to their close connections or to current customers if they share their experiences of using the services with those close to them. Social influence can come from family, colleagues, friends, and public figures who play key roles in changing people's points of view. This strategy is supported by previous empirical studies which have found that social influence has a strong relationship with customers' intention to use mobile banking in Pakistan (Asmy, Mohd \& Thaker, 2019). In addition, Islamic FinTech companies could also create online forums to make their activities visible to customers and investors. These forums could be used as platforms for all customers to enhance their knowledge and share their use of services with their social networks. This strategy could lead to a further increase in customers' trust in using Islamic FinTech services.

Moreover, given the importance of user-friendly features, Islamic FinTech companies should consider the behaviour of potential unbanked customers. According to Dupas, Karlan, Robinson \& Ubfal (2018), these customers normally prefer to use cash and other alternative service providers. They consider that 
non-transparent policies, rejection, long processes to obtain credit, and high fees are not relevant to their financial lives. Bachas, Gertler, Higgins \& Seira (2016) add that long transaction queues, limited branches in rural areas, and trust are other reasons for this situation. Islamic FinTech companies, as alternative financial providers, have a great opportunity to increase financial inclusion by offering financial products to unbanked customers and informal sectors based on daily wages. Wang et al. (2014) state that FinTech company should also consider the importance of system reliability and promptness, such as automatic replies, short waiting times, and frequently asked questions sections.

This study contributes to the understanding that government support plays an important role in the development of the Islamic FinTech industry and indirectly influences customers to use Islamic FinTech services. In response to the Covid-19 pandemic, the policies launched by the Central Bank of Indonesia concerning digital transformation and synergies between banking and FinTech have been vital in accelerating economic recovery (Bank Indonesia, 2020). The payment system policy is also directed at strengthening the momentum of national economic recovery, synergies between the government and other authorities, and expanding digital acceptance throughout Indonesia. Government support in promoting effective collaboration between stakeholders will establish a more stable ecosystem in the future.

In order to prioritise consumer protection, government regulation is needed concerning FinTech registration mechanisms, monitoring and supervision, business and data protection, risk management, consumer protection, and transparency. Consequently, customer trust will be increased and digital financial innovation will continue to develop, remain responsible and safe, and risks can be managed properly.

This study also offers several implications for the related theory. First, the findings expand the literature by incorporating government support with other factors such as perceived ease of use, perceived usefulness, perceived trust, and user innovativeness related to customers' intention to use Islamic FinTech services. Previous studies have largely focused on customer perception. This study has advanced understanding of the role of government support in developing Islamic FinTech, and its indirect influences on customers' continuance intention through perceived ease of use and perceived usefulness. Second, the study has advanced understanding of customers' intentions during crises. The related findings enrich the literature on Islamic FinTech by showing the major factors that could influence people's intention to use Islamic FinTech services during the Covid-19 pandemic.

\subsection{Limitations and Future Research}

The study has several limitations. First, the sample size is focused on Java Island and is small compared to the population of Indonesia, which might affect generalisation of the results. Future studies are encouraged to expand the research with more samples from other provinces in Indonesia. Second, the data collection method used was a survey. Future research should conduct in-depth interviews in order to gain deeper understanding of the impact of the Covid-19 pandemic on consumers' intention to use Islamic finance products, especially Islamic FinTech. 
Further research is also encouraged to add more variables, such as application features, religious beliefs, brand image, and physiological factors for intervening the factors and attitude behavior, as well as intention.

\section{REFERENCES}

Aboelmaged, M.G., \& Gebba, T.R. (2013). Mobilebanking adoption:An examination of technology acceptance model and theory of planned behavior. International Journal of Business Research and Development, 2(1), 35-50.

Adams, D. A., Nelson, R. R., \& Todd, P. A. (1992). Perceived usefulness, ease of use, and usage of information technology: A replication. MIS Quarterly 16(2), 227-247.

Agarwal, R., \& Prasad, J. (1999). Are individual differences germane to the acceptance of new information technologies? Decision Sciences, 30(2), 361-391.

Al Haderi, S. M. (2014). The influences of government support in accepting the information technology in public organization culture. International Journal of Business and Social Science, 5(5), 118-124.

Alaeddin, O., Rana, A., Zainudin, Z., \& Kamarudin, F. (2018). From physical to digital: Investigating consumer behaviour of switching to mobile wallet. Polish Journal of Management Studies, 17(2), 18-30.

Alam, N., Gupta, L., \& Zameni, A. (2019). Challenges and success factors for Islamic fintech. In Fintech and Islamic Finance (pp. 159-173). Palgrave Macmillan, Cham.

Aldila, N. (2020, August 26). Wapres: Layanan pembayaran syariah digital perlu diperluas [Vice President: Digital sharia payment services need to be expanded]. Retrieved on February 24, 2020, from https://finansial.bisnis. com/read/20200826/563/1282878/wapres-layanan-pembayaran-syariahdigitalperlu-diperluas.

Al nawayseh, M. K. (2020). Fintech in covid-19 and beyond: What factors are affecting customers' choice of Fintech Applications? Journal of Open Innovation: Technology, Market and Complexity, 6(4), 1-15.

Amalia, S. N. (2018). Faktor-faktor yang mempengaruhi minat individu terhadap financial technology pembayaran syariah paytren sebagai salah satu alat transaksi pembayaran: Pendekatan technology acceptance model dan theory of planned behavior. Iqtishaduna: Jurnal Ekonomi dan Keuangan Islam, 9(1), 6479.

Anderson, J. C., \& Gerbing, D. W. (1988). Structural equation modeling in practice: A review and recommended two-step approach. Psychological Bulletin, 103(3), 411-423.

Arora, N., Charm, T., Grimmelt, A., Ortega, M., Robinson, K., Sexauer, C., \& Yamakawa, N. (2020). A global view of how consumer behavior is changing amid COVID-19. Mcknsey and Company. July. Retrieved on from https://www. mckinsey.com/ /media/McKinsey/Business \%20Functions/Marketing\%20 and \%20Sales/Our\%20Insights/A\%20global\%20view\%20of\%20how\%20 consumer $\% 20$ behavior $\% 20$ is $\% 20$ changing $\% 20$ amid $\% 20$ COVID $\% 20$ 19/20200707/covid-19-global-consumer-sentiment-20200707.pdf

Ascarya, \& Rahmawati, S. (2018). Analysis of the determinants of micro enterprises graduation. Journal of Islamic Economics, Banking and Finance, 14(1), 1-49. 
Asmy, M., Mohd, B., \& Thaker, T. (2019). What keeps Islamic mobile banking customers loyal? Journal of Islamic Marketing, 10(2), 525-542.

Asosiasi Fintech Indonesia. (2018). Fintech landscape di Indonesia [Fintech landscape in Indonesia]. Retrieved on October 6, 2020, from https://klcfiles. kemenkeu.go.id/2019/08/4-Reynold-Wijaya-Fintech-Landscape-di-Indonesia. pdf.

Asosiasi FinTech Indonesia. (2020). Pemerintah gandeng AFTECH kembangkan ekonomi digital nasional guna tingkatkan daya saing UMKM [The government is collaborating with AFTECH to develop a national digital economy in order to increase the competitiveness of MSMEs]. Retrieved on February 20, 2020, from https://fintech.id/id/news/detail/Pemerintah-Gandeng-AFTECHKembangkan-Ekonomi-Digital-Nasional-Guna-Tingkatkan-Daya-SaingUMKM.

Bach, M. P., Čeljo, A., \& Zoroja, J. (2016). Technology acceptance model for business intelligence systems: Preliminary research. Procedia Computer Science, 100, 9951001.

Bachas, P., Gertler, P., Higgins, S., \& Seira, E. (2016). Banking on trust: How debit cards help the poor to save more. Documento sin publicar.

Bank Indonesia. (2020). Tinjauan kebijakan moneter Desember 2020 [Monetary policy review December 2020]. Retrieved on January 15, 2021, from https:// www.bi.go.id/id/publikasi/laporan/Pages/Tinjauan-Kebijakan-MoneterDesember-2020.aspx.

Barclay, D., Higgins, C. \& Thompson, R. (1995). The partial least squares (PLS) approach to causal modeling: Personal computer adoption and use as an illustration. Technology Studies, 2(2), 285-309.

Bella, F. I. (2020). Optimization of Islamic peer-to-peer lending for micro and small enterprises (MSEs) after pandemic of covid-19. Journal of Islamic Economic Laws, 3(2), 108-123.

Birchall, C. (2011). Introduction to "secrecy and transparency." The politics of opacity and openness. Theory, Culture E Society, 28(7-8), 7-25.

Boateng, H., Adam, D. R., Okoe, A. F., \& Anning-Dorson, T. (2016). Assessing the determinants of internet banking adoption intentions: A social cognitive theory perspective. Computers in Human Behavior, 65, 468-478.

Boomsma, A., \& Hoogland, J. J. (2001). The robustness of LISREL modeling revisited. In R. Cudeck, S. du Toit, \& D. Sörbom (Eds.). Structural equation models: present and future. A festschrift in honor of Karl Jöreskog (pp. 139-168). Scientific Software International.

Bourne, C. (2019). The public relations profession as discursive boundary work. Public Relations Review, 45(5), 101789.

Chang, Y., Wong, S. F., Lee, H., \& Jeong, S. P. (2016). What motivates Chinese consumers to adopt finTech services: a regulatory focus theory. Proceedings of the 18th annual international conference on electronic commerce: e-commerce in smart connected world, August 2016, No.40. https://doi.org/10.1145/2971603.2971643.

Chong, A. Y., Ooi, K., Lin, B., Tan, B. (2010). Online banking adoption: An empirical analysis. International Journal of Bank Marketing, 28(4), 267-287.

Davis, F. D. (1986). A technology acceptance model for empirically testing new end-user information systems: Theory and results [Ph.D. Thesis, Massachusetts Institute of Technology]. 
Davis, F. D., Bagozzi, R. P., \& Warshaw, P. R. (1989). User acceptance of computer technology: A comparison of two theoretical models. Management Science, 35(8), $982-1003$.

Davis, F. D. (1989). Perceived usefulness, perceived ease of use, and user acceptance of information technology. MIS Quarterly, 13(3), 319-340.

Darmansyah, Fianto, B. A., Hendratmi, A., \& Aziz, P. F. (2020). Factors determining behavioral intentions to use Islamic financial technology: Three competering models. Journal of Islamic Marketing, ahead-of-print.

Dupas, P., Karlan, D., Robinson, J., \& Ubfal, D. (2018). Banking the unbanked? Evidence from three countries. American Economic Journal: Applied Economics, 10(2), 257-297.

Elhajjar, S., \& Ouaida, F. (2019). An analysis of factors affecting mobile banking adoption. International Journal of Bank Marketing, 38(2), 352-367.

Etikan, I., Musa, S. A., Alkassim, R. S. (2015). Comparison of convenience sampling and purposive sampling. American Journal of Theoretical and Applied Statistics, $5(1), 1-4$.

Fadila, A. (2020, April 1). Bisnis fintech syariah terganggu wabah corona. Kontan. Retreived from https://keuangan.kontan.co.id/news/bisnis-fintech-syariahterganggu-wabah-corona.

Farooq, A., Laato, S., \& Islam, A.K.M.N. (2020). Impact of online information on self-isolation intention during the covid-19 pandemic: Cross-sectional study. Journal of Medical Internet Research, 22(5), 1-15.

Faturohman, T., Hassandi, I., \& Yulianti. (2020). User acceptance of online waqf applications: Evidence from Indonesia. Journal of Islamic Monetary Economics and Finance, 6(3), 503-530.

Fayad, R., \& Paper, D. (2015). The technology acceptance model e-commerce extension: A conceptual framework. Procedia Economics and Finance, 26(2015), 1000-1006. https://doi.org/10.1016/S2212-5671(15)00922-3.

Fedorko, I., Bacik, R., \& Gavurova, B. (2018). Technology acceptance model in e-commerce segment. Management $\mathcal{E}$ Marketing. Challenges for the Knowledge Society, 13(4), 1242-1256.

Fiorino, G., Colombo, M., Natale, C., Azzolini, E., Lagioia, M., Danese, S. (2020). Clinician education and adoption of preventive measures for Covid-19: A survey of a convenience sample of general practitioners in lombardy, Italy. Ann Intern, 173(5), 405-407. https://doi.org/10.7326/M20-1447.

Fornell, C. \& Larcker, D. F. (1981). Evaluating structural equation models with unobservable variables and measurement error. Journal of Marketing Research, XVIII(February), 39-50.

Garay,L.,Font, X., \&Corrons,A.(2019).Sustainability-orientedinnovationintourism: An analysis based on the decomposed theory of planned behavior. Journal of Travel Research, 58(4), 622-636. https://doi.org/10.1177/0047287518771215

Gbongli, K., Xu, Y., \& Amedjonekou, K, M. (2019). Extended technology acceptance model to predict mobile-based money acceptance and sustainability: A multi-analytical structural equation modeling and neural network approach. Sustainability, 11(3), 3639. https://doi.org/10.3390/su11133639.

Grabner-Krauter, S., \& Faullant, R. (2008). Consumer acceptance of internet banking: The influence of internet trust. International Journal of Bank Marketing, 26(7), 483-504. https://doi.org/10.1108/02652320810913855. 
Gupta, A., \& Arora, N. (2017). Consumer adoption of m-banking: A behavioral reasoning theory perspective. International Journal of Bank Marketing, 35(4), 733747. https://doi.org/10.1108/IJBM-11-2016-0162.

Hair, J.F., Ringle, C.M., \& Sarstedt, M. (2011). PLS-SEM: indeed a silver bullet. Journal of Marketing Theory and Practice, 19(2), pp. 139-151.

Hair, J.F., Black, W.C., Babin, B.J., \& Anderson, R.E. (2010). Multivariate data analysis. Seventh Edition. Upper Saddle River, New Jersey: Prentice Hall.

Hair, J., Ringle, C., \& Sarstedt, M. (2013). Partial least squares structural equation modeling: Rigorous application, better result and higher acceptance. Long Range Planning, 46(1-2), 1-12.

Hanafizadeh, P., Behboudi, M., Koshksaray, A. A., \& Tabar, M. J. S. (2014). Mobilebanking adoption by Iranian bank clients. Telematics and Informatics, 31(1), 6278.

Handoko, F., Smith, A., \& Burvill, C. (2014). The role of government, universities, and businesses in advancing technology for SMEs' innovativeness. Journal of Chinese Economic and Business Studies, 12(2), 171-180.

Hu, Z., Ding, S., Li, S., Chen, L., \& Yang, S. (2019). Adoption intention of fintech services for bank users: An empirical examination with an extended technology acceptance model. Symmetry, 11(3), 340-356.

Huei, C. T., Cheng, L. S., Seong, L. C., Khin, A. A., \& Bin, R. L. L. (2018). Preliminary study on consumer attitude towards fintech products and services in Malaysia. International Journal of Engineering \& Technology, 7(2.29), 166-169.

Hudaefi, F. A. (2020). How does Islamic fintech promote the SDGs? Qualitative evidence from Indonesia. Qualitative Research in Financial Markets, 12(4), 353366. https://doi.org/10.1108/QRFM-05-2019-0058.

Huh, H. J., Kim, T., \& Law, R. (2009). A comparison of competing theoretical models for understanding acceptance behavior of information systems in upscale hotels. International Journal of Hospitality Management, 28(1), 121-134.

Hulland, J. (1999), Use of partial least square (PLS) in strategic management research: A review of four recent studies. Strategic Management Journal, 20(2), 195-204.

Ibrahim, R., Leng, N. S., Yusoff, R. C. M., Samy, G. N., Masrom, S., \& Rizman, Z. I. (2017). E-learning acceptance based on technology acceptance model (TAM). Journal of Fundamental and Applied Sciences, 9(4S), 871-889.

Ichwan, \& Kasri. R. A. (2019). Why are youth intent on investing through peer to peer lending? Evidence from Indonesia. Journal of Islamic Monetary Economics and Finance, 5(4), 741-762

IMF (2020). A crisis like no other, an uncertain recovery. Retrieved on June 21, 2020 from https:/www.imf.org/en/Publications/WEO/Issues/2020/06/24/ WEOUpdateJune2020

Jin, C. C., Seong, L. C., \& Khin, A. A. (2019). Factors affecting the consumer acceptance towards fintech products and services in Malaysia. International Journal of Asian Social Science, 9(1), 59-65.

Kemmis, D. S. (2004). Innovation systems in Australia. ISRN 6th Annual Conference Working Paper, Canberra.

Khalil, T. M. (2000). The key to competitiveness and wealth creation. Management of Technology. Boston, MA: McGraw Hill. 
Kim, C., Mirusmonov, M., \& Lee, I. (2010). An empirical examination of factors influencing the intention to use mobile payment. Computers in Human Behavior, 26(3), 310-322.

Kim, Y., Park, Y.J., Choi, J. \& Yeon, J. (2015). An empirical study on the adoption of 'fintech' service: focused on mobile payment services. Advanced Science and Technology Letters, 114, 136-140. https://10.14257/ASTL.2015.114.26.

Kim, Y., Choi, J., Park, Y. J., \& Yeon, J. (2016). The adoption of mobile payment services for "Fintech". International Journal of Applied Engineering Research, 11(2), 1058-1061.

Kline, R. B. (1998). Principles and practice of structural equation modeling. New York: The Guilford Press.

Kline, R. B. (2011). Methodology in the social sciences. Principles and practice of structural equation modeling ( $3 \mathrm{rd}$ ed.). New York: The Guilford Press.

Lai, P. C. (2017). Security as an extension to TAM model: Consumers' intention to use a single platform E-Payment. Asia-Pacific Journal of Management Research and Innovation, 13(3-4), 110-119.

Leicht, T., Chtourou, A., \& Youssef, K. B. (2018). Consumer innovativeness and intentioned autonomous car adoption. The Journal of High Technology Management Research, 29(1), 1-11.

Lin, C. Y., \& Ho, Y. H. (2009). An empirical study on the adoption of RFID technology for logistics service providers in China. International Business Research, 2(1), 23-36.

Lockett, A., \& Littler, D. (1997). The adoption of direct banking services. Journal of Marketing Management, 13(8), 791-811.

Mahad, M., Mohtar, S., \& Othman, A. A. (2015). The effect of perceived trust of mobile banking services in Malaysia. International Academic Research Journal of Business and Technology, 1(2), 1-7.

Marakarkandy, B., Yajnik, N., \& Dasgupta, C. (2017). Enabling internet banking adoption: An empirical examination with an augmented technology acceptance model (TAM). Journal of Enterprise Information Management, 30(2), 263-294. Https://doi.org/10.1108/JEIM-10-2015-0094.

Mathew, A. Coronavirus impact: How to deal with a pay cut. Retrieved July 13, 2020, from https://www.bloombergquint.com/personal-finance/coronavirusimpact-how-to-deal-with-a-pay-cut.

McKinsey (2020). COVID-19: Briefing materials. Retrieved on July 13, 2020 from https://www.mckinsey.com/ /media/mckinsey/business\%20functions/risk/ our $\% 20$ insights/covid $\% 2019 \% 20$ implications $\% 20$ for $\% 20$ business/covid $\% 20$ 19\%20july\%209/covid-19-facts-and-insights-july-6.pdf.

Milian, E.Z., Spinola, M.D.M. \& Carvalho, M.M.D. (2019). Fintechs: A literature review and research agenda. Electronic Commerce Research and Applications, 34(March-April 2019), 100833.

Ministry of Finance of the Republic of Indonesia. (2020). Pemerintah berkomitmen bangun potensi ekonomi digital Indonesia [The government is committed to building the potential of Indonesia's digital economy]. Retrieved on February 24, 2020, from https://www.kemenkeu.go.id/publikasi/berita/ pemerintahberkomitmen-bangun-potensi-ekonomi-digital-indonesia/. 
Miskam, S., Yaacob A. M., \& Rosman, R. (2019). Fintech and its impact on Islamic fund management in Malaysia: A legal viewpoint. In Umar, A.O., Hassan, M.K. and Rusni, H. (Eds), Emerging Issues in Islamic Finance Law and Practice in Malaysia. Emerald Publishing Limited, pp. 223-246.

Montazemi, A. R., \& Qahri-Saremi, H. (2015). Factors affecting adoption of online banking: A meta-analytic structural equation modeling study. Information $\mathcal{E}$ Management, 52(2), 210-226.

Munoz-Leiva, F., Climent-Climent, S., \& Liébana-Cabanillas, F. (2017). Determinants of intention to use the mobile banking apps: An extension of the classic TAM model. Spanish Journal of Marketing-ESIC, 21(1), 25-38.

Natalia, M. (2020). Fintech beri dukungan masa pengendalian penyebaran dan penanganan covid-19 [Fintech provides support for controlling the spread and handling of Covid-19]. Retrieved on December 3, 2020 from https://ekbis.sindonews.com/berita/1559800/178/fintech-beri-dukungan-dimasapengendalian-penyebaran-dan-penanganan-covid-19.

Niswah, F. M., Mutmainah, L., \& Legowati, D. A. (2019). Muslim millenial's intention of donating for charity using fintech platform. Journal of Islamic Monetary Economics and Finance, 5(3), 623-644.

OJK. (2021). Perusahaan fintech lending berizin dan terdaftar di OJK [Fintech lending company licensed and registered in FSA]. Retrieved on February 24, 2020 from https://www.ojk.go.id/id/kanal/iknb/financialtechnology/ Documents/penyelenggara $\% 20$ berizin $\% 20$ terdaftar $\% 20$ per $\% 2022 \% 20$ Januari\%202021.pdf

Okcu, S., Koksalmis, G. H., Basak, E., \& Calisir, F. (2019). Factors affecting intention to use big data tools: an extended technology acceptance model. In Industrial Engineering in the Big Data Era (pp. 401-416). Springer, Cham.

Parent, M., Vandebeek, C. A. \& Gemino, A. C. (2005) Building citizen trust through e-Government. Government Information Quarterly, 22(4), 720-736.

Parizi, A. (2019). Perkembangan fintech syariah. Retrieved on October 6, 2020, from https://kseiprogres.com/perkembangan-fintech-syariah/

Park, E. J., Kim, E. Y., Forney, J. C. (2006). A structural model of fashion-oriented impulse buying behavior. Journal of Fashion Marketing and Management, 10(4), 433-446. https://doi.org/10.1108/13612020610701965.

Piskin, M., \& Kus, M. C. (2019). Islamic online P2P lending platform. Procedia Computer Science, 158, 415-419. https://doi:10.1016/j.procs.2019.09.070.

Pratama, W. P. (2020). Ada corona, permintaan pinjaman produktif fintech justru naik [There is a corona, the demand for fintech productive loans has actually increased]. Finansial. https://finansial.bisnis.com/read/20200505/563/1236689/ adacorona-permintaan-pinjaman-produktif-fintech-justru-naik.

Probst, W. N. (2020). How emerging data technologies can increase trust and transparency in fisheries. ICES Journal of Marine Science, 77(4), 1286-1294.

Rapyd. (2020). Asia Pacific eCommerce and Payments Guide 2020. https://cdn2. hubspot.net/hubfs/5246303/Asia\%20Pacific\%20eCommerce $\% 20$ and $\% 20$ Payments\%20Guide\%202020.pdf.

Riquelme, H. E., \& Rios, R. E. (2010). The moderating effect of gender in the adoption of mobile banking. International Journal of Bank Marketing, 28(5), 328341. 
Rogers, E. M. (2003). Diffusion of innovations. New York: Free Press.

Ryu, H. S. (2018). Understanding benefit and risk framework of fintech adoption: Comparison of early adopters and late adopters. In Proceedings of the 51st Hawaii International Conference on System Sciences. DOI: 10.24251/HICSS.2018.486.

Sari, F. (2020). Pinjaman fintech syariah capai Rp 1,7 triliun pada tahun 2020 [Islamic fintech lending reach IDR 1.7 trillion in 2020]. Retrieved on February 24, 2020, from ://keuangan.kontan.co.id/news/pinjaman-fintech-syariah-capairp-17-triliun-pada-tahun-2020.

Securities Commission Malaysia. (2020). Islamic finance a catalyst for financial inclusion. Retrieved on July 23, 2020, from https://www.sc.com.my/api/ documentms/download.ashx?id=824aa54c-ed70-4e56-a43e-ea629c8e5b6b

Sekhon, H., Sunikka, A., Peura-Kapanen, L., \& Raijas, A. (2010). Empirical investigation into the multi-faceted trust in the wealth management context. International Journal of Bank Marketing, 28(1), 65-81. https://doi. org/10.1108/02652321011013599.

Shaikh, I. M., Qureshi, M.A., Noordin, K., Shaikh, J.M., Khan, A \& Shahbaz, M. S. (2020). Acceptance of Islamic financial technology (FinTech) banking services by Malaysian users: An extension of technology acceptance model, Foresight, 22(3), 367-383.

Singh, S., \& Srivastava, K. R. (2020). Understanding the intention to use mobile banking by existing online banking customers: An empirical study. Journal of Financial Services Marketing, 25(3), 86-96.

Stanciu, S., Radu, R. I., Sapira, V. Bratoveanu, B. D., \& Florea, A. M. (2020). Consumer behavior in crisis situations. Research on the effects of covid-19 in Romania. Annals of "Dunarea de Jos" University of Galati: Fascicle I. Economics $\mathcal{E}$ Applied Informatics, 26(1).

Straub, D. W. (1994). The effect of culture on it diffusion e-mail and fax in Japan and the U.S. Information Systems Research, 5(1), 23-47.

Szopiński, T. S. (2016). Factors affecting the adoption of online banking in Poland. Journal of Business Research, 69(11), 4763-4768.

Turan, A., Tunc, A., \& Zehir, C. (2015). A theoretical model proposal: Personal innovativeness and user involvement as antecedents of unified theory of acceptance and use of technology. Procedia Social and Behavioral Sciences, $210(2$ December), 43-51.

United Nations of Development Programme. (2020). Results of the survey on impact of covid-19 to Indonesia's youth entrepreneurs in 2020. Retrieved on September 4, 2020, from https:/www.id.undp.org/content/indonesia/en/ home/presscenter/articles/2020/Results-of-the-Survey-on-the-Impact.html.

Ursachi, G., Zait, A., \& Horodnic, I. A. (2015). How reliable are measurement scales? External factors with indirect influence on reliability estimators. Procedia Economics and Finance, 20(2015), 679-686. https://doi.org/10/1016/ S2212-5671(15)00123-9.

Usman, H., Mulia, D., Chairy, C., \& Widowati, N. (2020). Integrating trust, religiosity and image into technology acceptance model: The case of the Islamic philanthropy in Indonesia. Journal of Islamic Marketing, ahead-of-print(ahead-ofprint). https://doi.org/10.1108/JIMA-01-2020-0020. 
Venkatesh, V., \& Bala, H. (2008). Technology acceptance model 3 and a research agenda on interventions. Decision Sciences Journal, 39(2), 273-315.

Venkatesh, V., \& Davis, F. D. (1996). A model of the antecedents of perceived ease of use development and test. Decision Sciences, 27(3), 451-481.

Wang, F., \& Chen, Y. (2012). From potential users to actual users: Use of e-government service by Chinese migrant farmer workers. Government Information Quarterly, 29(1), S98-S111.

Wang, Y. S., Wang, Y. M., Lin, H. H., \& Tang, T. (2014). Determinants of user acceptance of internet banking: An empirical study. International Journal of Service Industry Management, 14(5), 501-519.

Wiratmini, N. (2020, October 15). Salurkan dana PEN, Mandiri Syariah gandeng Fintech Alami [Distributing PEN funds, Mandiri Syariah collaborates with Alami Fintech]. Finansial. Retrieved on February 24, 2020, from https:// finansial.bisnis.com/read/20201015/231/1305436/salurkan-dana-pen-mandirisyariahgandeng-fintech-alami.

World Bank. (2020). Global covid-19 fintech market rapid assessment study. Retrieved from https://www.jbs.cam.ac.uk/faculty-research/centres/alternative-finance/ publications/2020-global-covid-19-fintech-market-rapid-assessment-study.

Yoon, Y., Guimaraes, T., \& O'Neal, Q. (1995). Exploring the factors associated with expert systems success. MIS Quarterly, 19(1), 83-106. https://doi. org/10.2307/249712.

Wong, K. K. K. (2013). Partial least squares structural equation modeling (PLSSEM) techniques using SmartPLS. Marketing Bulletin, 24(1), 1-32. 
This page is intentionally left blank 